\title{
Association of Affective Commitment with Organizational Citizenship Behaviour and Task Performance of Employees in Banking Sector
}

\section{Örgütsel Vatandaşıı Davranışına Efektif Bağlılık ile Bankacılık Sektöründeki Çalışanların Görev Performansı Arasında İlişkilendirme}

\author{
Dr. Rizwan Qaiser Danish, Hailey College of Commerce, University of the Punjab, \\ Pakistan, rdanish2000@yahoo.co.uk \\ Dr. Asad Afzal Humayon, COMSATS Institute of Information Technology, Vehari, \\ Pakistan, asadhumayon@ciitvehari.edu.pk \\ Ahmad Usman Shahid, COMSATS Institute of Information Technology, Vehari, \\ Pakistan, ahmadusman1990@ outlook.com
}

Muhammad Musarrat Nawaz, Punjab University Gujranwala Campus, Pakistan agoodperson@gmail.com

\begin{abstract}
The basic objective of this study was to determine the impact of organizational commitment especially affective commitment on extra role and in role performance of employees working in banks in the capital of Punjab, Lahore, Pakistan. In addition, the secondary purpose of this study was to explore what level of commitment the se employees demonstrate towards their organizations and what are their behaviours in performing jobs accordingly. So the present study had contributed to enhance the conception on noteworthy concerns and employees can enhance their performance by exhibiting such behaviours. In this survey based study, we collected data through self-administered questionnaires applying correlational explanatory research design. This study was conducted on the employees working in banks of Lahore, Pakistan. In March 2013, we circulated about 300 questionnaires among which 270 useable surveys were returned for a response rate of $90 \%$. The sample was sufficient for the application of Structural equation modeling in AMOS 18 and SPSS 20. The results of this study showed that affective commitment had positive impact on the extra role performance of employees working in banks. They feel themselves emotionally attached with their organizations, hence this higher level of affective commitment urge them to engage in Extra Role Performance. In Role Performance of employees of banks also got better due to their affective commitment with organizations. The sample of this study was employees who are working at public and private sector Banks in Lahore, Pakistan only. Research questionnaire was used to measure Organizational Commitment, Extra Role Performance and In Role Performance. Moreover qualitative research may also be conducted to further explore this area in Non Western context. Considering the importance of bankers' organizational commitment (affective commitment) and their effect on extra role performance (organizational citizenship behaviour) and in role behaviour or performance, higher management and policy makers should take necessary steps for improving the degree of commitment which will increase the extra role performance of employees. Some recommendations have been provided specifically.

Keywords: Affective Commitment, Extra Role Performance, In Role Performance, Organizational Citizenship Behavior, Banking
\end{abstract}

Sector.

Öz: Bu çalışmanın temel amacı Pencap eyaleti başkenti Lahor'daki bankalarda çalışanların örgütsel bağlllıklarının, özellikle duygusal bağlllıklarının ekstra görevler ve görev performansı üzerindeki etkisini belirlemektir. Buna ilaveten, ikinci amaç bu çalışanların örgütlerine karşı hangi seviyede bağlılık sergilediklerini ve işlerini yaparken buna bağlı olarak davranışlarının neler olduğunu ortaya koymaktır. Böylece bu çalışma, kayda değer kavramlara ilişkin algılara katkıda bulunacak ve çalı̧̧anlar bu davranışları sergileyerek performanslarını yükselteceklerdir. Bu anket bazlı çalışmada veri örneklemin kendisinin yanıtladĭ̆ anketler ile toplanmış ve veriye korelasyon temelli açıklayıcı araştırma tasarımı uygulanarak analiz edilmiştir. Bu çalışma Lahor, Pakistan'daki banka çalışanlarına uygulanmıştır. Mart 2013 'te gönderilen 300 anketin içinden 270 'i geri dönmüştür ve geri dönüşs oranı \%90'dır. Örneklem sayısı AMOS 18 ve SPSS 20 yazılımları ile yapısal eşitlik modelinin uygulanması için yeterlidir. Bu çalı̧̧manın sonuçlarl, banka çalışanlarının duygusal bağlılığının ekstra görev performansında pozitif etkisi olduğunu göstermiştir. Çalışanlar kendilerini örgüte bağll hissetmişler ve bu yüksek seviyedeki sadakat onların ekstra görev performansinda bulunmalarına yol açmıştır. Kendilerini duygusal olarak kuruma bağlı hissetmişler, bu yüksek bă̆lllı onların ekstra görev performansı göstermelerine yol açmıştır. Banka çalışanlarının duygusal görev sadakati nedeniyle görev performansları da iyileşmiştir. Çalışmanın örneklemi sadece Lahor, Pakistan'daki kamu ve özel sektör bankalarında görev yapan çalışanlardan oluşmaktadır. Araştırma anketi Örgütsel Bağlılı̆̆ı, Görev Performansı içinde Ekstra Görev Performansını ölçmek için kullanılmıştır. Bunun yanı sıra gelecekte aynı konunun farklı boyutları nitel araştırmalar ile batılı olmayan ortamlarda araştırılarak keşfedilebilir. Bankacıların örgütsel bağlllığı (duygusal sadakat) ve bu durumun ekstra görev alma performansına (örgütsel vatandaşlık davranışl) etkisi ve rol davranışı ile performansın önemi göz önüne alınırsa, üst düzey yöneticiler ve politika yapıcıların bağlılı̆̆ı arttırmak için gerekli adımları atması, çalışanların ekstra görev alma performansını arttıracaktır. Bu konu ile ilgili bazı önerilere yer verilmiştir.

Anahtar Kelimeler: Duygusal Bağlllık, Ekstra Görev Performansı, Görev Performansı İçinde, Örgütsel Vatandaşlık Davranışı, 


\section{Introduction}

The investigation of organizational commitment on job performance of employees is of great importance for top hierarchy of any organization. Commitment as a central aspect of organization can contribute towards the organizational efficiency. Performance of an individual is vital for his career growth and to remain a part of organization. As this performance depends on commitment through which that employee remains with the organization, committed the employees, higher the performance. Performance not only refers to working ability of an employee that is called in role behavior but also his attitude and behavior towards the organization, which we call extra role performance. The main goal of each organization is to get its predetermined target and it can be accomplished in the presence of excellent performance management system including an extra role and in role performance management system. In the study of organizational behavior, Organizational commitment refers to a psychological phenomenon that the employees hope to maintain their identity and relationship within the organization. (Meyer and Allen 1990, 1-18) constructed a broad study on the former organizational commitment scale and proposed at least three types of commitment: Affective commitment, which states to the individual's recognition to the organization ; Continuous commitment, which states that employees have to stay in the organization based on their cognition of the loss if they leave the organization ; Normative commitment, which states to a commitment that employees stay in the organization because of social obligation formed by a long term interaction (Meyer \& Allen 1991, 1-18). This study will not only show the effect of organizational commitment particularly affective commitment on employee's performance of financial sector of Lahore, Pakistan but also add to the prior literature to the extra role performance. Organizational citizenship behavior is the dimension of extra role performance which we will study in our research, and it comprises at organizational level and individual level. Our behavior at work also plays a vital role in our performance; this type of behavior (OCB) indirectly affects the performance and working of organization. In role behaviors (IRB) were explained by (Katz \& Kahn 1978) as those behaviors which are regular part of our job and completing routine office work which was assigned. As the banking sector plays critical role in economy of a country, the performance of employees in this sector needs to be measured through their attitude like commitment. In this study, the basic purpose is to investigate the impact of Affective Commitment on Organizational Citizenship Behavior and Task Performance of Employees working in Banking Sector, specifically in Pakistani context.

\section{Literature Review}

\subsection{Organizational commitment}

Commitment is " an effective connection to the objectives and ethics of an organization, one's participation in relation to objectives and values of organization and one's role to the organization for its own benefit , separately from its decently helpful value (Reyes et al 1990, 327-335) ." (Meyer \& Allen 1996, 252-276) suggested a three constituent concept of organizational commitment. These three constituents are affective commitment (AC), continuous commitment (NC) and normative commitment (CC). According to (Meyer \& Allen 1996, 252-276) the first constituent , affective commitment, states the employees expressive connection and association with the organization. The second constituent of organizational commitment, continuous commitment, states the commitment centred on the price that an employee associate with not resigning from the organization (Allen \& Meyer 1996, 1-18). (Meyer \& Allen 1996, 252-276) proposed that continuance commitment can be explained to refer something important that an employee have devoted in terms of time, struggle and money that seemed to be useless if he leave the organization. The cost of leaving organization may be intensified due to unavailability of substitutes to substitute the foregone investment or employees (Meyer \& Allen 1990, 327-335). The third constituent ,normative commitment, states the employee's understanding of responsibility to attach with the organization (Allen \& Meyer 1996, 252-276). This sense of responsibility is considered as a result from primary socialization procedures that could be cultural or family oriented and they are also being affected by the organization (Allen \& Meyer 1996, 1-18). Normative commitment can be hypothesized as conviction that "employees have to fulfil all the obligations for their organization (Bagraim 2003, 1327)". 


\subsection{Affective commitment}

Affective commitment stresses upon employees' expressive association and has been the repeatedly investigated element in studies of organizational commitment (Mathieu \& Zajac 1990, 171).The widespread methodology to organizational commitment in the literature is deliberated a passionate connection to the organization such that strongly committed individuals involves and enjoys association in the organization (Allen \& Meyer 1990, 1-18). Porter characterizes affective commitment by three factors (1) a wish to remain the member of the organization (2) confidence in and acknowledgement of organizational objectives and moral standards and (3) a readiness to emphasize on supporting the organization to achieve its objectives (Porter, Steers, Mowday, \& Boulian 1974, 603). Affective commitment has an impact on employee's job performance and its constituent, organizational citizenship behaviour.

\subsection{Organizational citizenship behavior $(\mathrm{OCB})$}

Job performance is the capability to perform excellently in our job that we have understood a comprehensive explanation of our job designation and to perform according to established standards and policies. Work behaviour that is beyond the customary measures of job performance but holds promise that long term organizational success in receiving hypothetical consideration as the challenge of worldwide competition give importance to the significance of organizational output, resilience and receptiveness to alter outdoor circumstances .In the last decade many terms have been used to label such behaviour like organizational citizenship behaviour (Organ et al 1988) and pro social organizational behaviour.

Organ, (1988) in the beginning proposed a five-section OCB model comprising altruism, courtesy, conscientiousness, civic virtue, and sportsmanship. According to Organ, (1988), sportsmanship can be defined as agreeableness by employees to face unfavourable conditions without making any complain ;civic virtue is attitude representative that personnel gives vigorous attention towards the lifespan of their institute; and conscientiousness is behaviour adopted by workers showing that employees admit and follow the instructions, conventions, and measures enacted by the organization. However, pragmatic investigation of (Bachrach, Bendoly, \& Podsakoff 1997, 1285) and (Posdakoff \& Mackenzie 1994, 351363) showed that managers frequently have difficulty in differentiating the other measurements in Organ's theoretical model and they considered altruism, peacekeeping and cheerleading as constituent of complete supporting measurement. Consequently, supporting behaviour is undoubtedly observed as second-order hidden perception covering these four perceptions (Altruism, peacekeeping and cheerleading) as distinguished by (Podsakoff, Ahearne, \& MacKenzie 1997, 262) these dimensions "evidently encompass the happening of work related difficulties".

Previous studies used organizational citizenship behaviour at individual level (OCBI) and organizational citizenship behaviour at organizational level (OCBO) to measure performance. Organizational citizenship behaviour (OCB) characterizes behaviour of a worker that is flexible but not directly acknowledged by the traditional incentive system means that is not the regular part of job but encourages the effective performance of the organization (Organ 1988). The applied significance of organizational citizenship behaviour (OCB) is that the organizational productivity and success is being upgraded by backing adaptability and innovativeness (Organ 1988). Empirical research in this context proposes two more categories of organizational citizenship behaviour (OCB): (a) OCBO-behaviours that provides advantage to the organization generally and (b) OCBI-behaviour that instantly benefit the specific employees and indirectly through its means to the organization.

The second major concept of OCB's is presented by (Williams \& Anderson 1991, 601-617). William and Anderson classify OCBs by focusing on the task or by behaviour of employee. They named the behaviours adopted for the wellbeing of other individuals as OCBI (organizational citizenship behaviour at individual level) and behaviours adopted for the benefit of the organization as OCBO (organizational citizenship behaviours at organizational level). William and Anderson initially acknowledged Organ's altruism aspect (Organ 1988) as a prototype of OCBI. Conversely, courtesy, peacemaking and cheerleading behaviours are focused to help to individuals and it is also suitable to consider them as dimension of OCBI. Similarly, William and Anderson considered Organ's compliance aspect as example of OCBO. Other researchers also considered civic virtues and sportsmanship in the category of OCBO 
(Hoffman, Blair, Meriac, \& Woehr 2007, 555) and (LePine, Erez, \& Johnson 2002, 52) and (Coleman \& Borman 2000, 25-44). In such a way all of Organ's (Organ 1988) OCB dimensions are apprehended by William and Anderson's theoretical model.

William and Anderson's research work added more OCB-associated dimensions in their classification of organizational citizenship behaviours. OCBI (organizational citizenship behaviours) not include altruism, peacekeeping and cheerleading of (Organ 1990, 43-72) but also interactive helping of Graham, (1989), social help of (Van Scotter \& Motowidlo 1996, 525) and social coordination of (Farh, Earley, \& Lin 1997, 421-444).

\subsection{In Role Behavior}

In role behaviours (IRB) were explained by (Katz \& Kahn 1978) as those behaviours which are regular part of job description and that part is formally rewarded. (Williams \& Anderson 1991, 601-617) explained in role behaviours (IRB) as completing routine office work which was assigned.

\subsection{The relationship of Affective commitment and performance of employees}

The relationship between organizational commitment and work performance is the subject matter which the scholars are concerned in the long history. (Luchak \& Gellatly 2007, 786) found a positive relation between performance and organizational commitment. (Bashaw nd Grant 1994, 41-67) searched a positive relation between performance and organizational commitment in study of industrial sales persons. (Meyer 1997, 175-228) proposed that there exists a strong relationship between job performance and organizational commitment where the workers strongly regulate their performance. (Suliman and Iles 2000, 407-422) studied organizational commitment in three industrial sectors in Jordan, their findings explored that organizational commitment has three dimensions and there is a positive relation between organizational commitment and job performance. (Khan, Jam, and Ramay 2010, 292-298) who took a sample of 153 public and private area employees working in oil and gas sector in Pakistan suggested that there is positive relationship between affective commitment and employee's performance. (Bolon 1997, 221) specified that affective commitment is the most influential commitment constituent in relations to illuminating alteration in organizational citizenship behaviours OCB, which is the constituent of job performance. Employees with affective commitment are motivated to work hard for the wellbeing of their organization, thus explaining the relationship with performance and organizational citizenship behaviours (OCB). Former researchers proved a positive relationship between employee's performance and continuous commitment. For example (Khan et al 2010, 292-298) in their study "the impact of organizational commitment on employees job performance " found that continuous commitment had positive relation with employees job performance. Normative commitment is a feeling of obligation , well-mannered and truthful workers can do work effectively having less opportunities (Green et al 2008, 1-32). Workers with high organizational commitment are more agreeable to work for the benefit of their organization and stay as a member of the organization; it results in high level of productivity in the organization.

Specific models of commitment that indirectly support a link with OCB have been provided by (Scholl 1981, 589-599) and (Wiener 1982, 418-428). Organizational citizenship behaviours (OCBO's) that affect the organization completely include behaviours such as public virtue, sportsmanship and assiduousness. OCBI's or organizational citizenship behaviours focused at other persons comprise the Selflessness and courteousness dimensions within the organizational environment. Scholl's model defines commitment as "a steady factor that performs to sustain trend of behaviour of an employee when expectancy conditions are not fulfilled and don not act". OCBs denotes behaviours that occurs as a result of expectations arisen due to official rewards in response to their better performance while commitment refers to appropriate factor relates to one's participation in relation to values and objectives of organization that will indirectly increase the performance of organization . Dedicated workers are pleased to be a part of the organization and feels for the wellbeing of the organization (George \& Jones 1996). Previous studies proposed that there exists a strong relationship between organizational commitment and organizational citizenship behaviour of an employee. Meyer, Allen \& Smith proposed that the employees who have affective commitment stay with the organization because they wish to remain attached to the organization (Meyer, Allen, \& Smith 1993, 538). 
Hence on the basis of above arguments following hypothesis and model can be developed.

\subsection{Hypotheses development}

To validate the research hypotheses, the research methodology is given here under $\mathrm{H}$ 1: There is positive relationship between affective commitment and extra role performance or organizational citizenship behavior

$\mathrm{H} 1$ (a): There is positive relationship between affective commitment and organizational citizenship behavior at organizational level (OCBO).

$\mathrm{H} 1$ (b): There is positive relationship between affective commitment and organizational citizenship behavior at individual level (OCBI).

$\mathrm{H}$ 2: There is positive relationship between affective commitment and in role behavior (IRB).

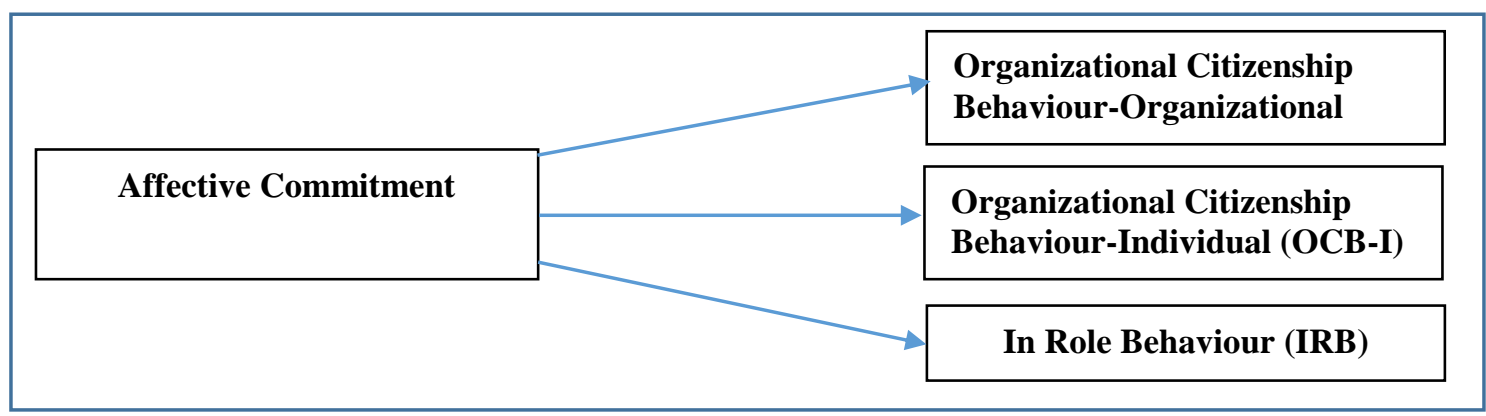

Figure 1. Theoretical Framework

\subsection{Methodology}

Survey questionnaires were circulated to three hundred employees working in public and private sector banks of capital of Punjab, Lahore Pakistan. Various modes of communication such as personal interviews were conducted and questionnaires were filled from employees in order to get maximum responses. Of 300 distributed questionnaires overall useable response rate was about 90 percent (270) collected from the employees of banking sector of Lahore, Pakistan through convenient sampling. Five points Likert scale was used to measure level of commitment with job and the organizational citizenship behaviour and in role behaviour. Affective commitment was measured by using six items scale developed by (Meyer et al., 1993) . Organizational citizenship behaviour and in role behaviour was measured by twenty one items scale focusing on organizational citizenship behaviour at organizational level (OCBI) ,organizational citizenship behaviour at individual level (OCBI) and in role behaviour (IRB) established by (Williams \& Anderson, 1991). Hypotheses were tested through correlation analysis and structural equation modelling (SEM).

\subsection{Sample}

The study was conducted on the employees of banking sector of capital of Lahore, Pakistan regarding the effect which organizational commitment has on the performance and behaviour of the employees.

\subsection{Data collection and data analysis}

The data is of primary nature as it is collected directly from the employees of banking sector of Pakistan through a research questionnaire and then it is analyzed using SPSS and AMOS in this study AMOS 18.0 was used to apply the confirmatory factor analysis to test the measurement model.

\subsection{Tables}

Table1.0 indicates the descriptive statistics (mean, standard deviation), reliability coefficients and Pearson correlation statistics of independents and dependent variables. The mean value for Affective Commitment, 3.54 is lower and for In Role Behavior 3.95, is higher. The correlation results shows that 
there exist a significantly moderate relation between Organizational Citizenship Behavior, In Role Behavior and Affective commitment

Table 1. Descriptive statistics

\begin{tabular}{llllllll}
\hline & Mean & $\begin{array}{l}\text { Standard } \\
\text { Deviation }\end{array}$ & $\begin{array}{l}\text { Reliability } \\
\alpha\end{array}$ & $\begin{array}{l}\text { Affective } \\
\text { commitment }\end{array}$ & (0CBO) & (0CBI) & (IRB) \\
\hline Affective commitment & 3.5426 & 0.73168 & 0.725 & 1 & & & \\
OCB-O & 3.8815 & 0.59336 & 0.570 & $.324^{* *}$ & 1 & & \\
OCB-I & 3.8844 & 0.65189 & 0.618 & $.286^{* *}$ & $.472^{* *}$ & 1 & \\
IRB & 3.9556 & 0.64855 & 0.574 & $.183^{* *}$ & $.462^{* *}$ & $.473^{* *}$ & 1 \\
\hline
\end{tabular}

\subsection{Measurement model}

Measurement model displayed as a path diagram, in this diagram circles or ovals represent unobserved measured indicators of factors (observed variables). The figure 1. has 4 latent variables in circles that are manifested by 13 observed variables in squares. Single-headed arrows represent a trend of assumed causal influence and co variance between two latent variables represented by double headed arrows. Latent variables "cause" the observed variables shown by the single-headed arrows towards the observed variables pointing away from the circle.

Table 2. Standardized regression weights

\begin{tabular}{lll}
\hline Latent variable & Item & Standardized \\
& label & Factor Loading \\
\hline Affective Commitment (AC) & Q1 & .661 \\
& Q2 & .440 \\
Organizational Citizenship Behavior - Individual (OCBI) & Q3 & .593 \\
& Q2 & .624 \\
& Q26 & .620 \\
& Q27 & .825 \\
Organizational Citizenship Behavior - Organization (OCBO) & Q28 & .622 \\
& Q29 & .611 \\
In Role Behavior (IRB) & Q31 & .328 \\
& Q32 & .573 \\
& Q36 & .527 \\
Q37 & .442 \\
& Q38 & .715 \\
Q39 & .809 \\
& Q41 & .330 \\
& Q42 & .730 \\
\end{tabular}




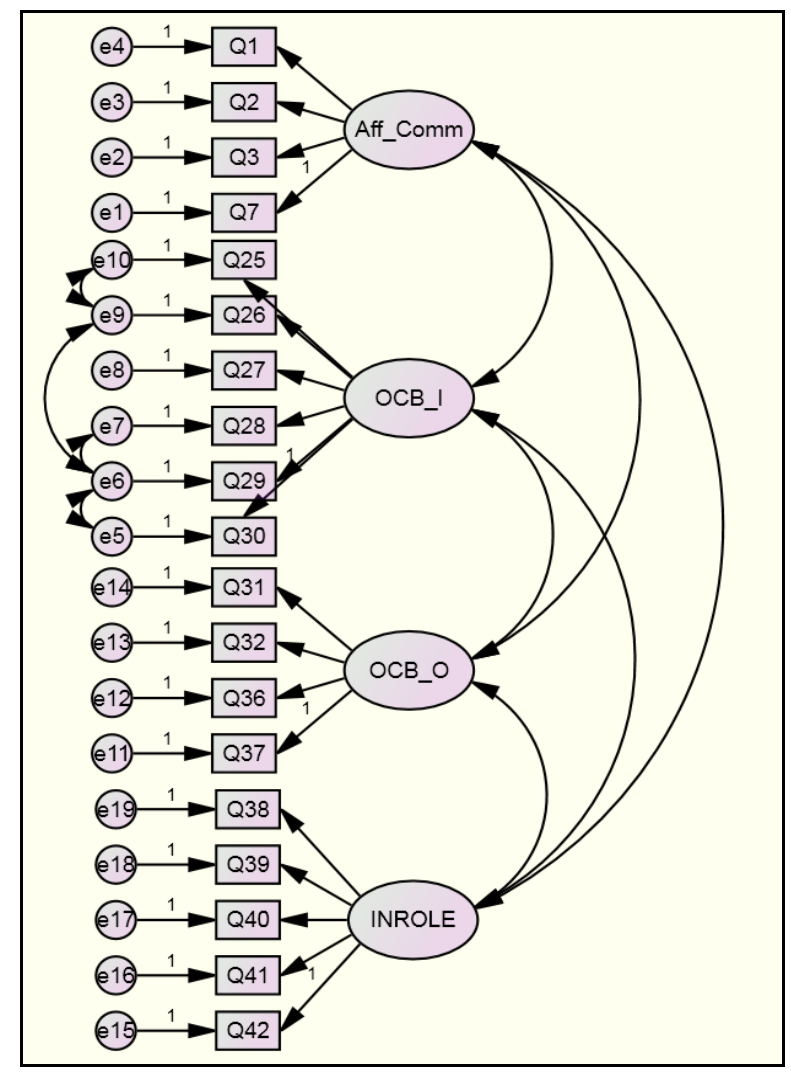

Figure 2. The measurement model

\subsection{Evaluating model fitness}

AMOS gives a set of indices which are affective to evaluate whether or not the data confirmed to the hypothesized model. These indices reveal the degree to which the variables associate with one another as the model would estimate. In this study Chi square, CMIN/DF, Comparative fit indices (CFI), Goodness of Fit Index (GFI), Adjusted Goodness of Fit Index (AGFI) and Route Mean Square Error of Approximation (RMSEA) were used to evaluate the model fitness.

Chi square is a common goodness-of-fit evaluator to find out overall model fitness. Chi square value of 374 with $142 \mathrm{DFs}$, is significant at $\mathrm{p}<0.001$. Dividing chi square value by degree of freedom we get 2.63 which indicates a good fit within the recommended range of less than 5(Carmines \& McIver, 1981), CMIN/DF (the likelihood ratio of chi square) value is $2.63<5$ indicates a good fit.

Another commonly reported statistic is the Goodness of Fit Index (GFI) as its name suggest. If its value closer to 0.90 or higher indicates a good fit while the Adjusted Goodness of Fit Index value (AGFI) is 0.80 reflect a good fit. In this study, the measurement model is perfect fit model where GFI value is 0.921 and AGFI value is 0.887 .

Comparative fit index (CFI) examines the fit of a user-specified solution relative to a limited baseline model in which the covariance's among all variables is hypothesized as fixed to zero or no association among input indicators. The CFI values varieties from 0 to 1 .The value of CFI nearer to 1 interprets the model as very good fit (Hu \& Bentler 1999, 1-55).

Another measure of fit is the root mean square error of approximation (RMSEA), integrates a punishment function for poor model parsimony. This index is believed to indicate a good fit if it is 0.06 or less, which confirms that our model is good and acceptable (Hu \& Bentler 1999, 1-55) In the measurement model, RMSEA index is 0.057 indicates a good fit . An RMR smaller value leads towards goodness of model. In the measurement model RMR value is 0.047 indicates a good fit. Overall summary of model fit is given in table 3 . 
Danish, R.Q., Shahid, A.U. /Journal of Yasar University, 2015, 10/Special Issue, 56-67

Table 3. Model fit summary

\begin{tabular}{lll}
\hline Model fit indices & Measurement & Threshold \\
\hline X2 & 374 & \\
CMIN/DF & 2.636 & $<3$ good $;<5$ Permissible \\
CFI & 0.847 & Closer to $1 ;$ Good \\
GFI & 0.879 & $>0.90$ \\
AGFI & 0.838 & $<0.80$ \\
RMR & 0.047 & $<0.06$ \\
RMSEA & 0.057 & $<0.06$ \\
PCLOSE & 0.000 & $>0.05$ \\
\hline
\end{tabular}

Overall results indicated that the measurement model accepted as a good fit with the help of Chi-Square, CMIN/DF, CFI, GFI, AGFI, RMR, RMSEA and PCLOSE indices.

\subsection{Structural model equation}

In structural equation modelling (SEM), complex relationship between observed and unobserved variables are tested and relationships between two or more latent variables are also examined .In figure 2. and 3. at first, overall model fitness is established after that researcher examine whether specific paths are significant or not. In this study, a model using structural equation modelling was established.

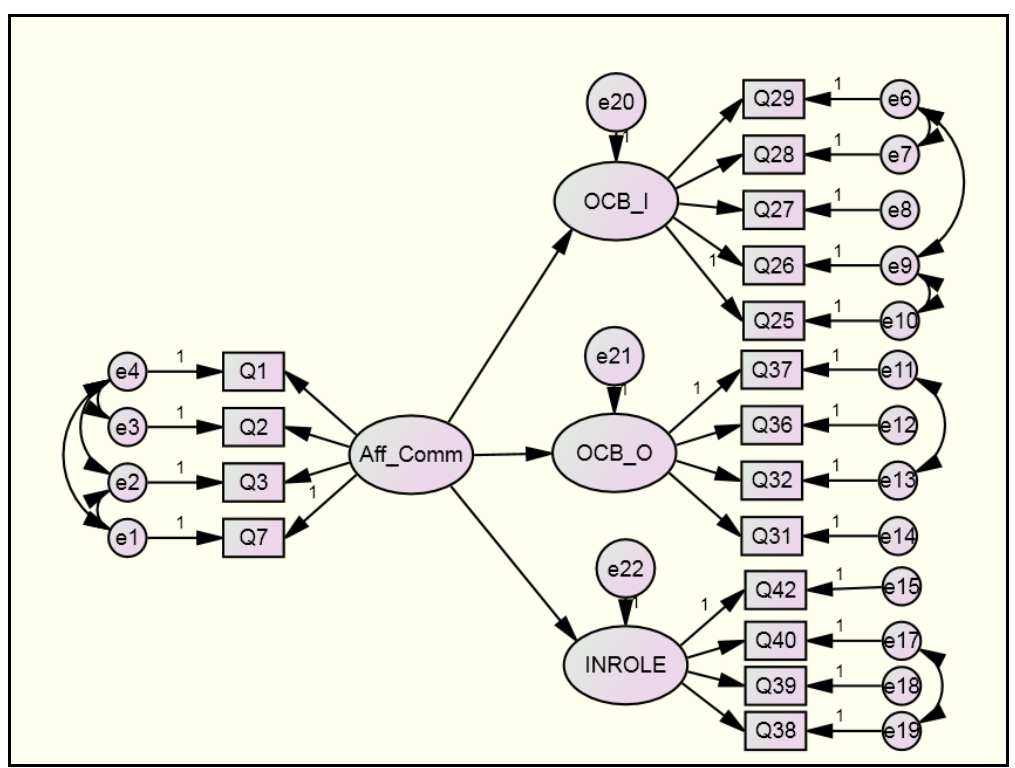

Figure 3. Structural Model relating Affective Commitment to OCB-I, OCB-O and IRB 


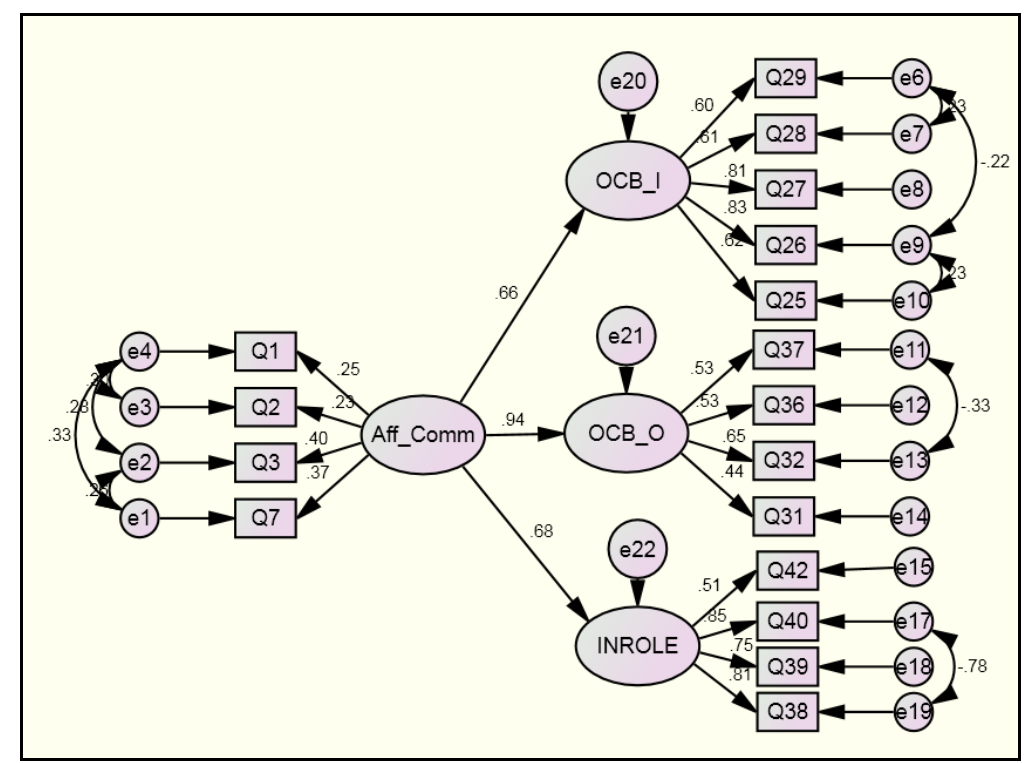

Figure 3. Structural Model with Path Coefficients

In this model (Figure 2. and 3.), draws path from organizational citizenship behaviour at individual level (OCBI), organizational citizenship behaviour at organizational level (OCBO) and in role behaviour (IRB) towards affective commitment. Table given below the standard estimates check out the model fitness by using model fit indices mentioned in the box. CMIN/DF value is 1.871 which suggests that the above model is fit because its value is less than 3. The value of GFI and AGFI indicates that the model has fitness because all values are near to 0.90. RMSEA and RMR values are 0.047 and 0.057 whish are below from 0.10 suggests that the model is statistically fit. Above all fit indices revealed that the fitness of model is acceptable.

Table 4. Model Fitness

\begin{tabular}{lllllll}
\hline CMIN/DF & RMR & GFI & AGFI & CFI & RMSEA & PCLOSE \\
1.871 & 0.047 & 0.921 & 0.887 & 0.932 & 0.057 & 0.170 \\
\hline
\end{tabular}

\subsection{Table for standardized estimates}

Table 5. Standardized Regression Weights: (Group number 1 - Default model)

\begin{tabular}{llll}
\hline & & & Estimate \\
\hline OCB_I & $<---$ & Aff_Comm & .663 \\
OCB_O & $<---$ & Aff_Comm & .939 \\
INROLE & $<---$ & Aff_Comm & .676 \\
\hline
\end{tabular}

These variables showed significant and positive association with Affective commitment because regression weight of relationships exceeds 0 .

\section{Findings}

It is found that all the proposed hypotheses are fully supported in our study after analyzing results and these findings are related to both public and private sector banks of Lahore, Pakistan. Organizational affective commitment has a moderately positive impact on extra role performance and in role performance of employees. It is approved that if an employee demonstrate commitment towards organization then he behaves in a positive manner and performs his job duties in a proper way. Thus it is approved that affective commitment of employees improves their behaviour and performance. Employees 
are always keen to improve their overall performance for improving the performance of their organization, they think and work for the development of organization.

\section{Limitations}

Like all other empirical research studies, this research study has also some of the limitations. It is felt that sample size is not enough to represent the whole industry and there is a slight possibility that the future research in the same industry may yield a little bit different results. Another limitation is generalizing the findings from this study. Data was gathered from a specific city (i.e. Lahore).thus the results may not be applicable to other cities of Pakistan.

\section{Directions for future research}

This study provides an integrated model to understand and better explain the relationships between organizational affective commitment, organizational citizenship behaviour and in role behaviour of employees in banking sector of Pakistan. Hope so, this research study will stimulate the researchers to begin to think deliberately about how the affective commitment relates to Extra Role Performance constituting organizational citizenship behaviour (OCB) and in role behaviour (IRB) and how the organizational commitment helps to contribute into the enhancement of citizenship behaviours in the organizations. In the 21 st century it is very important for the organizations that they must develop such strategies that help them to make employees committed to the organizations.

\section{Conclusion}

The present study is an attempt to find the relationship between an aspect of organizational commitment (Affective Commitment) and key determinants of extra role performance (organizational citizenship behaviour and in role behaviour). Some important findings of the study are that affective commitment moderately correlates with the key determinants of extra role performance. The employees having affective commitment with the organization not only perform well according to their job description but also behave positively for the wellbeing of organization and for them. Organizations create affective commitment for their employees due to their positive behaviour and performance. Employees struggle when their organization appreciate their work, reward them, respect them and consider them as a vital part of the organization. The employees efficiently do their jobs, effectively behave in the organization and remain loyal to their organization. Employee affective commitment and organizational citizenship behaviour can be improved by devoting attention on human resource management (HRM) practices which will provide a guideline in this regard. 


\section{REFERENCES}

Allen, N.J.\& Meyer, J.P. 1990. "The measurement and antecedents of affective, continuance and normative commitment to the organization" Journal of Applied Psychology 63(1):1-18.

Allen, N.J. \& Meyer, J.P. 1996. "Affective, continuance, and normative commitment to the organization: An examination of construct validity" Journal of Vocational Behavior 49(3): 252-276.

Bachrach, D.G, Bendoly, E. \& Podsakoff, P.M. 2001. "Attributions of the" causes" of group performance as an alternative explanation of the relationship between organizational citizenship behavior and organizational performance" Journal of Applied Psychology 86(6): 1285.

Bagraim, J. J. 2003. The nature and measurement of multiple commitment foci amongst South African knowledge workers. Mit.Dyn. 12(2): 13-23.

Bashaw, E., Grant, S. 1994. "Impact of job formalization and administrative control on attitudes of industrial salespersons distinctive nature of work commitments: their relationship with personal characteristics, job performance and propensity to leave" Journal of Personal Selling and Sales Managemen 14: 41-67.

Bolon, D. S. 1997. “Organizational citizenship behavior among hospital employees: a multidimensional analysis involving job satisfaction and organizational commitment" Hospital and Health Services Administration 42(2): 221.

Carmines, E. G. \& McIver, J. P. 1981. "Analyzing models with unobserved variables: Analysis of covariance structures" Social measurement: Current issues 65-115.

Coleman, V. I. \& Borman, W.C. (2000). Investigating the underlying structure of the citizenship performance domain. Human Resource Management Review 10(1): 25-44.

Farh, J. L., Earley, P. C. \& Lin, S. C. 1997. "Impetus for action: A cultural analysis of justice and organizational citizenship behavior in Chinese society" Administrative Science Quarterly 421444.

George, J. M. \& Jones, G. R. 1996. Understanding and managing organizational behavior: AddisonWesley Pub.(Reading, Mass.).

Graham, J. W. 1989. Organizational citizenship behavior: Construct redefinition, operationalization, and validation Unpublished working paper Loyola University of Chicago, Chicago, IL, 68.

Green F. 2008. "Leeway for the loyal: A model of employee discretion" British Journal of Industrial Relationship 46(1): 1-32.

Hoffman, B. J., Blair, C. A., Meriac, J. P. \& Woehr, D. J. 2007. "Expanding the criterion domain? A quantitative review of the OCB literature" Journal of applied psychology 92(2): 555.

Hu, L. T. \& Bentler, P .M. 1999. "Cutoff criteria for fit indexes in covariance structure analysis: Conventional criteria versus new alternatives" Structural Equation Modelingv 6(1): 1-55.

Katz, D. \& Kahn, R. L. 1978. The social psychology of organizations.

Khan, M. R., Jam, F. A., \& Ramay, M. 2010. "The Impacts of Organizational Commitment on Employee Job Performance" Europeon Journal of Social Sciences, 15(3): 292-298.

LePine, J. A., Erez, A. \& Johnson, D. E. 2002. "The nature and dimensionality of organizational citizenship behavior: a critical review and meta-analysis" Journal of Applied Psychology 87(1): 52.

Luchak, A. A. \& Gellatly, I. R. 2007. "A comparison of linear and nonlinear relations between organizational commitment and work outcomes" Journal of Applied Psychology 92(3): 786.

Mathieu, J. E. \& Zajac, D. M. 1990. "A review and meta-analysis of the antecedents, correlates, and consequences of organizational commitment" Psychological Bulletin 108(2): 171.

Meyer, J. P. 1997. “Organizational commitment” International Review of Industrial and Organizational Psychology 12: 175-228.

Meyer, J. P. \& Allen, N. J. 1984. "Testing the" side-bet theory" of organizational commitment: Some methodological considerations" Journal of Applied Psycholog, 69(3): 372.

Meyer, J. P. \& Allen, N. J. 1991. "A three-component conceptualization of organizational commitment" Human Resource Management Review 1(1): 61-89. 
Meyer, J. P., Allen, N. J. \& Smith, C. A. 1993. "Commitment to organizations and occupations: Extension and test of a three-component conceptualization" Journal of Applied Psychology 78(4): 538.

Organ, D. W. 1988. Organizational citizenship behavior: The good soldier syndrome: Lexington Books/DC Heath and Com.

Organ, D. W. 1990. "The motivational basis of organizational citizenship behavior" Research in Organizational Behavior 12(1): 43-72.

Podsakoff, P. M., Ahearne, M. \& MacKenzie, S. B. 1997. "Organizational citizenship behavior and the quantity and quality of work group performance" Journal of Applied Psychology 82(2): 262.

Porter, L. W., Steers, R. M., Mowday, R. T. \& Boulian, P. V. 1974. "Organizational commitment, job satisfaction, and turnover among psychiatric technicians" Journal of Applied Psychology 59(5): 603.

Posdakoff, P. M. \& Mackenzie, S. B. 1994. "Organizational citizenship behaviors and sales unit effectiveness" Journal of Marketing Research 351-363.

Reyes, P. 1990. "Individual work orientation and teacher outcomes" Journal of Educational Research 327-335.

Scholl, R. W. 1981. "Differentiating organizational commitment from expectancy as a motivating force" Academy of Management Review 6(4): 589-599.

Suliman, A. \& Iles, P. 2000. "Is continuance commitment beneficial to organizations? Commitmentperformance relationship: a new look" Journal of Managerial Psychology 15(5): 407-422.

Van Scotter, J. R. \& Motowidlo, S. J. 1996. "Interpersonal facilitation and job dedication as separate facets of contextual performance" Journal of Applied Psychology 81(5): 525.

Wiener, Y. 1982. "Commitment in organizations: A normative view" Academy of Management Review, 7(3): 418-428.

Williams, L. J. \& Anderson, S. E. 1991. "Job satisfaction and organizational commitment as predictors of organizational citizenship and in-role behaviors” Journal of Management 17(3): 601-617. 